\title{
Effects of Vitamin E by dietary supplementation and of Calcium Ascorbate by post mortem Injection in Muscle on the Antioxidative status and on Meat quality of Pigs
}

\begin{abstract}
The effects of addition of vitamin $\mathrm{E}$ to pig diet and of calcium ascorbate injection in meat on the antioxidative status and meat quality (longissimus muscle) of pigs were investigated. The treatment consisted of supplementation with vitamin E (500 $\mathrm{mg} \alpha$-tocopheryl acetate/kg diet) for a minimum of 30 days to growingfinishing pigs before slaughter. Furthermore, meat samples (longissimus muscle) were injected with $10 \%$ by weight of a $1.5 \%$ calcium ascorbate solution. The dietary supplementation of fat soluble antioxidant vitamin $\mathrm{E}$ significantly $(\mathrm{P}<0.05)$ increased the concentration of $\alpha$-tocopherol in meat (longissimus muscle). Lipid oxidation measured as TBARS, and antioxidative capacity $\left(\mathrm{Fe}^{2+} /\right.$ ascorbate induced) of meat were significantly $(\mathrm{P}<0.05)$ influenced by the supplementation with vitamin $\mathrm{E}$, and the $\mathrm{pH}_{1}$ and driploss was improved. Water soluble antioxidant calcium ascorbate, injected in meat, increased the concentration of calcium $(\mathrm{P}<0.05)$ and ascorbic acid $(\mathrm{P}<0.05)$, and stabilized the colour ("a" value; $\mathrm{P}<0.05)$ in chill-stored meat and improved $(\mathrm{P}<0.05)$ the antioxidative capacity ( $\mathrm{Fe}^{2+} /$ ascorbate induced). Further research is needed to optimise the dosage.
\end{abstract}

Key Words: pig, vitamin E, calcium ascorbate, lipid oxidation, meat quality

\section{Zusammenfassung}

Titel der Arbeit: Auswirkungen einer Futtersupplementierung mit Vitamin E sowie einer Injektion von Calciumascorbat in den Muskel post mortem auf den antioxidativen Status und die Fleischqualität beim Schwein

In einem Experiment mit Schweinen wurde der Effekt einer Futtersupplementierung mit Vitamin E sowie die Injektion von Calciumascorbat in das Fleisch (M. longissimus) auf den antioxidativen Status und auf die Fleischqualität untersucht. Die Vitamin E Supplementierung (500 mg $\alpha$-tocopherylacetat $/ \mathrm{kg}$ Futter) wurde in einem Zeitraum von mindestens 30 Tagen vor dem Schlachten vorgenommen. Die Injektion in das Fleisch erfolgte mit einer 10\%igen Calciumascorbat-Lösung (10\% Gewichtsanteil zum Fleisch). Die Futtersupplementierung mit Vitamin E erhöhte die $\alpha$-tocopherol Konzentration im Fleisch signifikant. Die Lipidoxidation, gemessen als TBARS und die antioxidative Kapazität (induziert durch $\mathrm{Fe}^{2+} / \mathrm{Ascorbat)}$ wurden durch die Supplementierung signifikant beeinflusst und der $\mathrm{pH}_{1}$ sowie der Dripverlust wurden signifikant verbessert. Das in das Fleisch injizierte Calciumascorbat erhöhte sowohl die Calciumkonzentration als auch die Konzentration von Ascorbinsäure. Weiterhin wurde der Farbwert „a“ des Fleisches bei einer Lagerung stabilisiert. Für eine optimale Dosierung sind weitere Untersuchungen notwendig.

Schlüsselwörter: Schwein, Vitamin E, Calciumascorbat, Lipidoxidation, Fleischqualität

\section{Introduction}

Vitamin $\mathrm{E}$ is considered as the principal antioxidant defence agent against lipid oxidation in cell membranes in mammals. The advantages of vitamin $\mathrm{E}$ supplementation (commonly used as $\alpha$-tocopheryl acetate) at supranutritional levels in the diet of pigs to increase the oxidative stability of phospholipids in the subcellular muscle membranes have been shown (ASGHAR et al., 1991; MONAHAN et al, 1994; 
FLACHOWSKY, 2000). Dietary supplementation of vitamin $E$ increases the concentration of $\alpha$-tocopherol in muscle and reduces the susceptibility of the muscle to lipid peroxidation (BUCKLEY et al., 1995). The recommended level of dietary $\alpha-$ tocopheryl acetate supplementation in growing pigs is 15 to $40 \mathrm{mg} / \mathrm{kg}$ of feed (ALBERS et al, 1984). However, some meat quality parameters and the oxidative stability improve when dietary $\alpha$-tocopheryl acetate levels are higher (200 to 500 $\mathrm{mg} / \mathrm{kg}$ diet) as was shown by several researches (ASGHAR et al., 1991; MONAHAN et al., 1994; BUCKLEY et al., 1995; CHEAH et al., 1995; LAHUCKY et al., 2000, 2001). The studies showed the beneficial effects of vitamin $E$ on lipid peroxidation in meat (NUERNBERG et al., 2002), usually evaluated as TBARS (thiobarbituric reactive substances) concentration. Skeletal muscle is particularly susceptible to oxidative reactions since it contains high concentrations of prooxidants (transition metals, haem-containing proteins, i.e. myoglobin, haemoglobin) and membrane lipids which contain high percentages of polyunsaturated fatty acids (KANNER, 1994).

Vitamins $\mathrm{E}$ and $\mathrm{C}$ are primary antioxidants in biological systems and break the chain of lipid peroxidation. Some studies suggest that vitamin $\mathrm{C}$ and vitamin $\mathrm{E}$ act synergistically (GEY, 1998; EICHENBERGER et al., 2001). In the body, vitamin E (mainly as $\alpha$-tocopherol) is found in the lipid, while vitamin C (ascorbic acid) is an outstanding antioxidant in plasma and aqueous compartments (ROCK et al, 1996). Lascorbic acid is unstable when exposed to either oxygen or certain minerals, and this can result in a rapid oxidation to the dehydroascorbic acid derivative. Ascorbate contributes to the development of a more stable colour of cured products and acts as a synergist to antioxidants (SOFOS and BUSTA, 1980). There is a consistent epidemiological evidence about the protective effect of vitamin $\mathrm{C}$ against heart disease (GEY, 1998). Calcium ascorbate (E-302) is employed as antioxidant and preservative in concentrated milk products, in cooked, cured or pulverized meat products, and in pickles in which pork and beef products are cured and packed (RUTH, 1989).

The objective of this study was to evaluate further the effects of dietary vitamin $\mathrm{E}$ supplementation and calcium ascorbate injected into the muscle postmortem on levels of $\alpha$-tocopherol, ascorbic acid and calcium in muscle, the antioxidative capacity, and parameters of meat quality.

\section{Material and Methods \\ Animals and sample preparations}

In total 20 pigs were used in this experiment. They originated from lines of Slovak White Meaty pigs. The RYR-1 genotype (FUJII et al., 1991) of these animals was determined by a DNA based test described previously (BAUEROVA et al., 1999).

The experiments were in accordance with the institutional guidelines for animal care (Research Institute of Animal Production, Nitra, 1999).

The 20 pigs were equally divided in the control group and the experimental group (10 pigs each: $5 \mathrm{MH}$ normal $=2$ barrows and 3 gilts, $5 \mathrm{MH}$ heterozygote $=2$ barrows and 3 gilts). The pigs were penned in double boxes at the institute (RIAP) facilities.

The control group (group C) received standard diet. The experimental group (group E) received a supplemental level of $\alpha$-tocopherol (500 $\mathrm{mg} / \mathrm{kg}$ diet) as source of vitamin $\mathrm{E}$ (ROVIMIX $^{\circledR}$ E-50 SD) for approximately 40 days (minimum 30 days) before slaughter. The levels of $\alpha$-tocopherol and ascorbic acid in the diets are shown in Table 1 (Protocol 1222-1223/2004, Central Control Institute of Agriculture, Bratislava). 
Table 1

Composition and nutrition value of the diet (Zusammensetzung und Nährwert des Futters)

\begin{tabular}{lclrr}
\hline Item & \% (Weight) & Item & Group C & Group E \\
\hline Wheat & 24.0 & Organic matter, \% & 82.15 & 82.15 \\
Barley & 40.0 & Crude protein, \% & 17.42 & 17.42 \\
Oat & 10.0 & Crude fat, \% & 2.79 & 2.79 \\
Soybean meal & 12.0 & Crude fibre, \% & 4.51 & 4.51 \\
Wheat meal & 4.0 & N-free extract, \% & 57.43 & 57.43 \\
Lucerne meal & 3.0 & Ash, \% & 5.63 & 5.63 \\
Meat and bone meal & 2.0 & Metabolisable energy, MJ & 12.38 & 12.38 \\
Fish meal & 1.0 & Lysine, \% & 0.91 & 0.91 \\
Mineral supplement & 3.0 & a-tocopherol-added, mg/kg & - & 500.00 \\
Fodder salt & 0.4 & - analysed, mg/kg & 35.50 & 524.00 \\
Biofactor supplement & 0.6 & Vitamin C-added, mg/kg & - & - \\
& & -analysed, mg/kg & 92.40 & 90.80 \\
\hline
\end{tabular}

The animals were stunned, slaughtered and exsanguinated in the slaughter house of RIAP Nitra (transportation about $200 \mathrm{~m}$ ) with an average live weight of $110 \mathrm{~kg}$. After $24 \mathrm{~h}$ chilling $\left(3-4^{\circ} \mathrm{C}\right)$, the longissimus muscle was removed from the carcass (right side) and then sliced into chops (three pieces $2.5 \mathrm{~cm}$ thick). One piece of loin from each pig was used as a control (no injection, group $\mathrm{C}$, group $\mathrm{E}$ ). Two pieces were treated with calcium ascorbate (group $\mathrm{C}+$ Asc, group E+Asc). Treatments consisted of injecting (needle injector, MEDART, Slovakia) the muscle with $10 \%$ by weight of solution of $1.5 \%$ Ca ascorbate (Sigma-Aldrich, $1.5 \mathrm{~g} / 100 \mathrm{~g}$ water) with approximately $2.5 \mathrm{~cm}$ distances. Following injection, the muscle sections were covered with aluminium film to prevent evaporative losses and to allow equilibration (for $5 \mathrm{~min}$ ), and were than wrapped in aluminium film.

One wrapped sample was stored in a refrigerator for 5 days at $4^{\circ} \mathrm{C}$, and a second wrapped sample was frozen at $-25^{\circ} \mathrm{C}$ until analysing.

\section{Chemical analysis}

The concentration of vitamin E ( $\alpha$-tocopherol) in muscle was measured by HPLC (BERLIN et al., 1994). For vitamin C (ascorbic acid) the methodology of DAVIDEK (1981) and OMAYE et al. (1979) with 2,4-dinitrophenylhydrazin as a colour reagent was used (in cooperation with State Veterinary and Food Institute, Bratislava). Lipid oxidation was assessed by the 2-thiobarbituric acid method of SALIH et al. (1987) and was expressed as mg of malondialdehyde produced per $\mathrm{kg}$ of sample. For evaluating the peroxidative stability of longissimus homogenates the determination of thiobarbituric acid reactive substances (TBARS) was used (KUECHENMEISTER et al., 1999). TBARS were expressed in equivalents of malondialdehyde (nM/mg homogenate protein), a breakdown product formed during peroxidation stimulated by $\mathrm{Fe}^{2+} /$ ascorbate. The protein content of homogenates was estimated by a modified method of MARKWELL et al. (1978). Calcium was determined by atomic absorption spectrophotometry according to the AOAC method (AOAC, 1995). Total protein and intramuscular fat were measured by the Infratec-Analyser.

\section{Meat quality measurements}

The $\mathrm{pH}$ value of the carcass (longissimus muscle between $13^{\text {th }}$ and $14^{\text {th }}$ rib) was determined using a combined $\mathrm{pH}$ electrode (Ingold). Instrumental colour measurements were recorded for $\mathrm{L}^{*}$ (lightness; 0: black, 100: white), $\mathrm{a}^{*}$ 
(redness/greenness; positive values: red, negative values: green), and $b^{*}$ (yellowness/blueness; positive values: yellow, negative values: blue) using a Spectrophotometer (Hunter Lab MiniScan). Drip loss analysis was made according to HONIKEL et al. (1998). Shear force was determined on cooked samples (core temperature of $80^{\circ} \mathrm{C}$ ) using a Warner-Bratzler apparatus.

\section{Statistical analysis}

The data were analysed with the procedure GLM of the Statistical Analysis Package SAS. The statistical model included the fixed effects gender, genotype, and experimental group. The ANOVA showed no interactions between these effects. The gender was of no influence, however, the genotype was shown to be of influence on $\mathrm{pH}_{1}$, colour $\mathrm{L}^{*}$, and on driploss. These effects were taken care of by calculating the least-squares means (LSM) and the standard errors (SE) including these effects in the calculations. The tables and figures contain the LSM and the SE.

\section{Results}

The results of the crude protein, moisture and intramuscular fat of meat (longissimus muscle) $24 \mathrm{~h}$ after slaughter (Table 2) show no differences between dietary treatments with different levels of vitamin E. Also, the difference in the concentration of vitamin $\mathrm{C}$ was not significant $(\mathrm{P}>0.05)$.

\section{Table 2}

Chemical composition and level of vitamin E and C of longissimus muscle (Chemische Zusammensetzung und Gehalt an Vitamin E und C im Longissimusmuskel)

\begin{tabular}{lcccc}
\hline Trait & Group C & Group E & SE & P-value \\
\hline Total water, \% & 73.46 & 73.49 & 0.337 & 0.950 \\
Total protein, \% & 22.10 & 22.44 & 0.132 & 0.085 \\
Intramuscular fat, \% & 3.31 & 2.88 & 0.339 & 0.378 \\
Vitamin E, mg/kg & 2.54 & 4.89 & 0.159 & $<0.0001$ \\
Vitamin C, mg/kg & 25.07 & 25.72 & 1.278 & 0.721 \\
\hline
\end{tabular}

The supplementation with vitamin E (500 mg $\alpha$-tocopheryl acetate/kg diet) increased $(\mathrm{P}<0.05)$ the $\alpha$-tocopherol level (Table 2$)$ of fresh $(24 \mathrm{~h})$ meat compared to that observed in pigs fed a basal level of $\alpha$-tocopheryl acetate (35.5 mg/kg diet, Table 1) The $\mathrm{pH}_{1}$ in longissimus muscle was higher $(\mathrm{P}<0.05)$ and drip loss was lower by about $1 \%$ in longissimus muscle of pigs supplemented with vitamin $\mathrm{E}$ (Table 3). The $\mathrm{pH}_{24}$, conductivity, colour, and TBARS (24 h) in longissimus muscle were not significantly $(\mathrm{P}>0.05)$ influenced by supplementation with vitamin $\mathrm{E}$.

Table 3

Meat quality of longissimus muscle (Fleischqualität des Longissimusmuskels)

\begin{tabular}{lcccc}
\hline Trait & Group C & Group E & SE & P-value \\
\hline $\mathrm{pH}_{1}$ & 6.03 & 6.24 & 0.20 & 0.033 \\
$\mathrm{pH}_{24}$ & 5.43 & 5.35 & 0.04 & 0.134 \\
Conductivity - 3 h, mS & 3.71 & 3.40 & 0.38 & 0.570 \\
Conductivity - 24 h, mS & 6.77 & 5.83 & 0.62 & 0.294 \\
Drip loss, \% & 4.53 & 3.48 & 0.20 & 0.002 \\
Colour L* & 50.9 & 49.0 & 1.09 & 0.213 \\
TBARS, mg/kg & 0.24 & 0.21 & 0.01 & 0.108 \\
\hline
\end{tabular}

Supplementation of Ca ascorbate (1.5\%) by injection into the meat chops (longissimus muscle) $24 \mathrm{~h}$ post mortem increased vitamin C (ascorbate) concentrations, determined 
following a 5 day storage (Table 4). The concentration of calcium (longissimus muscle) showed a significant increase $(\mathrm{P}<0.05)$ in the modified meat (supplemented with $\mathrm{Ca}$ ascorbate). The colour parameters "a" value improved $(\mathrm{P}<0.05)$ in groups injected with Ca ascorbate compared to control group. The TBARS values were higher in groups without supplementation of vitamin E. No significant differences $(\mathrm{P}>0.05)$ were received in shear force values.

Table 4

Effect of calcium ascorbate injection on Ca and ascorbate (Vit. C) level and meat quality values after storage (5 days) of longissimus muscle (see Material and Methods) (Einfluss einer Injektion mit Calciumascorbat auf den Calcium- und Ascorbatgehalt sowie die Fleischqualität des Longissimusmuskels nach einer Lagerung von 5 Tagen)

\begin{tabular}{lccccc}
\hline Trait & Group C & Group C+Asc & Group E & Group E+Asc & SE \\
\hline Ca, mg/kg & $0.168^{\mathrm{a}}$ & $0.233^{\mathrm{b}}$ & $0.156^{\mathrm{a}}$ & $0.214^{\mathrm{b}}$ & 0.011 \\
Vit. C, mg/kg & n.d. & 274.8 & n.d. & 277.9 & 12.0 \\
Colour L* & 51.34 & 50.56 & 50.61 & 50.42 & 0.837 \\
$\quad \mathrm{a}$ & $2.29^{\mathrm{a}}$ & $3.05^{\mathrm{b}}$ & $2.42^{\mathrm{a}, \mathrm{b}}$ & $3.00^{\mathrm{a}, \mathrm{b}}$ & 0.262 \\
b & 9.46 & 9.63 & 8.99 & 9.30 & 0.346 \\
TBARS, mg/kg & $0.290^{\mathrm{a}}$ & $0.287^{\mathrm{a}}$ & $0.235^{\mathrm{b}}$ & 0.259 & 0.015 \\
Shear force, kp & 5.18 & 4.98 & 4.94 & 4.75 & 0.209 \\
\hline
\end{tabular}

within a row, means with different superscript letter differ $(\mathrm{P}<0.05)$

n.d. not determined

The Figure shows the development of TBARS (expressed as nM MDA/mg homogenate protein) after incubation of homogenates of frozen stored muscle. Whereas the TBARS of the control was steeply increasing during the incubation, the increase was significantly $(\mathrm{P}<0.05)$ lower in the vitamin $\mathrm{E}$ group and also in groups with Ca ascorbate injected meat.

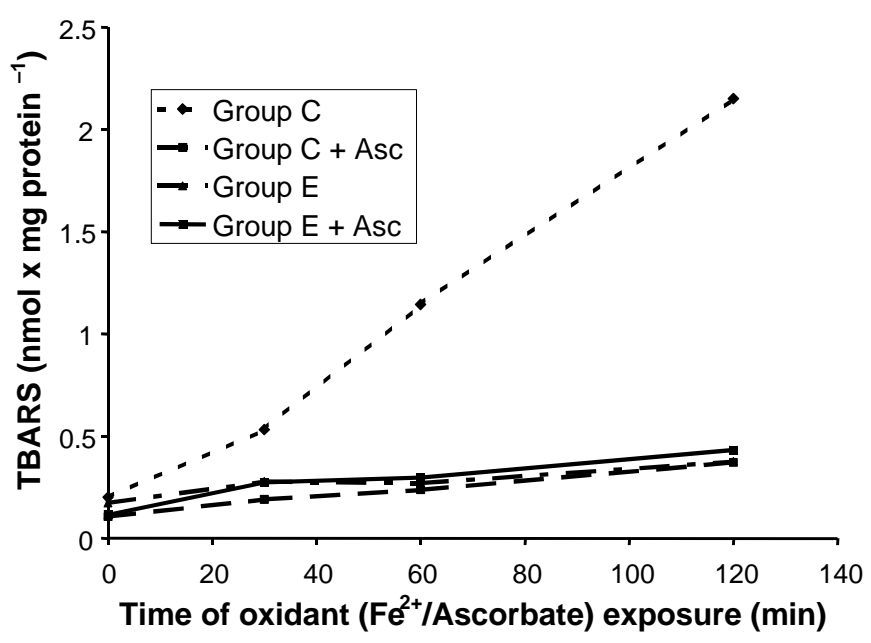

Figure: Peroxidative stability of longissimus muscle homogenate. The muscle homogenate was incubated for different time intervals with $\mathrm{Fe}^{2+}$ /ascorbate. The TBARS values of the Control group are significantly different from that of the other groups (Peroxidative Stabilität der Homogenate des Longissimusmuskels. Die TBARS-Werte der Kontrollgruppe (Group C) unterscheiden sich signifikant von denen der anderen Gruppen)

\section{Discussion}

The levels of $\alpha$-tocopherol in longissimus muscle in the present study are comparable with previously reported results (BUCKLEY et al., 1995; LAHUCKY et al., 2001; NUERNBERG et al., 2002). 
It is known (Den HERTOG-MEISCHKE et al., 1997; KRSKA et al., 2001) that the effect of vitamin E supplementation on meat quality values depends on the muscle. As was shown earlier (CHEAH et al., 1995) using a higher level of vitamin $E(\alpha-$ tocopherol) supplementation (500 $\mathrm{mg}$ and or $1000 \mathrm{mg} / \mathrm{kg}$ diet) administered for 46 days positively influenced the drip loss and $\mathrm{pH}$ in unfrozen longissimus thoracis muscle in MH-heterozygotes and in MH-normal pigs. KERTH et al.(2001) showed, that the supplementation of at least 600 IU of vitamin $\mathrm{E}$ in the finishing diet of $\mathrm{MH}-$ normal pigs drastically reduced quality defects of the muscle. Some results (HONIKEL et al., 1998) did not show positive effects of vitamin E supplementation on $\mathrm{pH}$ and drip loss. The discrepancy found in the literature regarding meat quality values (mainly drip loss, $\mathrm{pH} 45$ ) could also be a consequence of different levels and time of vitamin E administration and/or unknown (and different number) halothane (malignant hyperthermia) gene status of pigs as was discussed earlier (LAHUCKY et al. 2001). Our results, showing no differences in colour (Table 3), are in agreement with others (HONIKEL et al., 1998, LAHUCKY et al., 2001).

A higher "a" value in Ca ascorbate injected muscle after a five days chill storage (Table 4) could be connected to a reducing activity of ascorbic acid on metmyoglobin. Ascorbic acid could play a role in maximizing muscle colour stability by metmyoglobin reduction as was discussed by LEE et al. (1999). Recently, MANCINI et al. (2004) showed that application of ascorbic acid (2.5\%) prevented lumbar vertebrae discoloration during a five day display at $1^{\circ} \mathrm{C}$. Using higher concentrations of $\mathrm{Ca}$ ascorbate $(29.17 \mathrm{~g} / \mathrm{kg})$ in fermented sausages, significant higher "a" values and lower "L*" values were received (GIMENO et al., 2001). As was introduced by CONOLLY and DECKER (2004), addition of exogenous antioxidants with strong reducing activity (ascorbic acid) to postmortem tissue can partially convert peroxinitrite oxidized metmyoglobin back to oxymyoglobin and could help preserve colour.

There are only few results regarding shear force (tenderness) in pigs supplemented with vitamin E (LAHUCKY et al., 2001; WAYLAN et al., 2002). $\mathrm{Ca}^{2+}$ transport as well as increased intracellular $\mathrm{Ca}^{2+}$ concentration should be of influence on tenderness (KUECHENMEISTER and KUHN, 2003). In our experiment, there was no improvement in tenderness by diet supplementation of vitamin $\mathrm{E}$ and/or by injection of Ca ascorbate into the meat (Table 4). As was shown by SHEARD and TALI (2004) marination with different salt solutions (sodium tripolyphosphate and/or sodium bicarbonate) could reduce the shear force. Also, results reported by MONTGOMERY et al. (2000) that dietary vitamin $\mathrm{D}_{3}$ given 9 days before slaughter improved tenderness of 14 days aged beef (interaction vitamin $\mathrm{E}$ and $\mathrm{D}_{3}$ ) were shown to be promising.

It has been proposed that a high level of vitamin $\mathrm{E}$ in the diet might reduce the damaging oxidation of meat, and this area has been reviewed extensively (MORRISSEY et al., 1994; BUCKLEY et al., 1995). The dietary level of vitamin E (group $\mathrm{E}$ and group $\mathrm{E}+\mathrm{Asc}$ ) positively influenced the lipid oxidation. It has been stated that additional vitamin $\mathrm{C}$ can either exhibit antioxidative or prooxidative effects (WONG et al., 2005). Different mechanisms of fat soluble (vitamin E) and water soluble (vitamin C) antioxidants can be expected (ROCK et al., 1996). For further studies different levels of $\mathrm{Ca}$ ascorbate (or acid ascorbate) injection in meat and using TEAC (Trolox equivalent antioxidant capacity) to evaluate water soluble (or total) antioxidants (ARTS et al., 2004) would be useful. 
The possibility to slow the formation of peroxidative degradation products (MDA) in such systems is an indication of its antioxidative capacity (NUERNBERG et al., 2002; LAHUCKY et al., 2004). The illustrated differences (Figure) substantiate the protective action of feed supplemented with vitamin $\mathrm{E}$ and/or vitamin $\mathrm{C}$ incorporated into the muscle tissue against peroxidation. Such a beneficial effect of dietary vitamin $E$ on the oxidative stability of pork chops and ground meat after storage has been also shown by others (ASGHAR et al., 1991; LAHUCKY et al., 2001; NUERNBERG et al., 2002).

From the data it is clear that a higher level of vitamin $\mathrm{E}$ in the pig's diet improves the oxidative stability of pork. To take the greatest advantage of cooperative effects with other antioxidants (ascorbic acid), it is necessary to clearly define the dosages to be administered, bearing in mind the results to be achieved.

In agreement with others (ISABEL et al., 2003) administration strategies for improving meat quality and antioxidative stability characteristics are not commonly used due to extra feeding costs, which are difficult to be recovered in the commercial setting. However, the relative higher added value of processed meats compared to fresh meat could provide an economic advantage by the use of administration (antemortem and/or postmortem) strategies for reducing deterioration during storage, or for improving quality characteristics. This provides an interesting area of research to define strategies to optimise quality, and their possible interactions with technological processes.

Further research is needed to optimise the dosage.

\section{Acknowledgements}

This research was supported by state subprogram "Foods - quality and safety" No. 2003SP270280E010280E01 and partially by the Ministry of Agriculture in Bonn (Germany) and the Ministry of Agriculture in Bratislava (Slovak Republic).

\section{References}

ALBERS, N.G.; BEHM, W.; KLAUS, K.; KUTHNER, K.; LIDNER, H.:

Vitamin in animal nutrition. Arbeitsgemeinschaft fuer Wirkstoffe in der Tierernaehrung. (1984), Bonn, Germany

AOAC.

Determination of calcium, magnesium and phosphorus in cheese. In Official Methods of analysis $\left(16^{\text {th }}\right.$ ed.). Arlington, VA: Association of Official Analytical Chemists. 1995

ARTS, M.J.T.J.; DALLINGA, J.S.; VOSS, H.-P.; HAENEN, G.R.M.M.; BAST, A.:

A new approach to assess the total antioxidant capacity using the TEAC assay. Food Chemistry 88 (2004) 4, 567-570

ASGHAR, A.; GRAY, J.I.; BOOREN, A.M.; GOMMA, E.A.; ABOZIED, M.M.; MILLER, E.R.:

Effect of supranutritional dietary vitamin E levels on subcellular deposition of $\alpha$-tocopherol in the muscle and on pork quality. Journal of the Science of Food and Agriculture 57 (1991), 31-41

BAUEROVA, M.; BAUER, M.; VASICEK, D.:

A simple and inexpensive DNA purification for malignant hyperthermia PCR detection in porcine hair roots. Meat Sci. 51 (1999), 325-327

BERLIN, E.; MCCLURE, D.; BANKS, M.A.; PETERS, R.C.:

Heart and liver fatty acid composition and vitamin E content in miniature swine fed diets containing corn and menhaden oils. Comparison Biochemical and Physiological 109 A (1994) 1, 53-61

BUCKLEY, D.J.; MORRISSEY, P.A.; GRAY, I.I: Influence of dietary vitamin $\mathrm{E}$ on the oxidative stability and quality of pig meat. J. Anim. Sci. 73 (1995), 3122-3131

CHEAH, K.S.; CHEAH, A.M.; KRAUSGRILL, D.I.:

Effect of dietary supplementation of vitamin E on pig meat quality. Meat Sci. 39 (1995), 255-264 
CONNOLLY, B.J.; DECKER, E.A.:

Peroxynitrite induced discoloration of muscle foods. Meat Sci. 66 (2004), 499-505

DEN HERTOG-MEISCHKE, M.J.A.; SMULDERS, F.J.M.; HOUBEN, J.H.; EIKELENBOOM, G.: The effect of dietary vitamin E supplementation on drip loss of bovine longissimus lumborum, psoas major and semitendinosus muscles. Meat Sci. 45 (1997), 153-160

DAVIDEK, J.:

(Spectrophotometric estimation of L-ascorbic, L-dehydroascorbic and 2,3-diketo-L-gulonic acid with 2,4-dinitrophenylhydrazine). SNTL, ALFA, Prag (1981), 341-342

EICHENBERGER, B.; GEBERT, S.; WENK, C.: Interaktion von Vitamin E und C in verschiedenen Geweben beim wachsenden Schwein. Vitamine und Zusatzstoffe in der Ernaehrung von Mensch und Tier. 8. Symposium, Jena/Thueringen, 2001, 325-328

FLACHOWSKY, G.: Vitamin E-transfer from feed in to pig tissues. Journal of Applied Animal Research 17 (2000), 69-80.

FUJII, J.; OTSU, K.; ZORZATO, F.; DE LEON, S.; KHANA, V.K.; WEILER, J.; O’BRIEN, P.J.; MAC LENNAN, D.H.:

GEY, K.F.: Identification of a mutation in the porcine ryanodine receptor that is associated with malignant hyperthermia. Science, Washington 253 (1991), 448-451

Vitamins E plus C and interacting conutritiens required for optimal health. BioFactors 7 (1998), 113174

GIMENO, O.; ASTIASARAN, I.; BELLO, J.:

Calcium ascorbate as a potential partial substitute for $\mathrm{NaCl}$ in dry fermented sausages: effect on colour, texture and hygienic quality at different concentrations. Meat Sci. 57 (2001), 23-29

HONIKEL, K.O.; ROSENBAUER, H.; FISCHER, K.; MULLER, W.D.; PRZYTULE, J.:

Einfluss von Vitamin E und Rapsöl auf Qualitätsmerkmale von Schweinefleisch und daraus hergestellten Produkten. Fleischwirtschaft, 78 (1998), 1205-1207

ISABEL, B.; LOPEZ-BOTE, C.J.; de al HOZ, L.; TIMON, M.; GARCIA, C.; RUIZ, J.:

Effects of feeding elevated concentrations of monounsaturated fatty acids and vitamin $\mathrm{E}$ to swine on characteristics of dry cured hams. Meat Sci. 64 (2003), 475-482

KANNER, J.:

Oxidative processes in meat and meat products: quality implications. Meat Sci. 36 (1994), 169-189

KERTH, C.R.; CARR, M.A.; RAMSEY, C.B.; BROOKS, J.C.; JONSON, R>C.; CANNON, J.E.; MILLER, M.F.:

Vitamin-mineral supplementation and accelerated chilling effects on quality of pork from pigs that are monomutant or noncarriers of the halothane gene. J. Anim. Sci. 79 (2001), 2346-2355

KRSKA, P.; LAHUCKY, R.; KUECHENMEISTER, U.; NUERNBERG, K.; PALANSKA, O.; BAHELKA, I.;

KUHN, G.; ENDER, K.:

Effect of dietary organic selenium and vitamin E supplementation on post mortem oxidative deterioration in muscles of pigs. Arch. Tierz., Dummerstorf 44 (2001), 193-201

KUECHENMEISTER, U.; NUERNBERG, K.; FIEDLER, I.; KUHN, G.; NUERNBERG, G.; ENDER, K.:

Cell injury and meat quality of pig in the time period post mortem from two genotypes susceptible or resistant to malignant hyperthermia. Eur. Food Res. Technolol. 209 (1999), 97-103

KUECHENMEISTER, U.; KUHN, G.:

Regulation of intracellular $\mathrm{Ca}^{2+}$ concentration and meat quality in pigs. Arch. Tierz., Dummerstorf 46 (2003), 445-454

LAHUCKY, R.; KRSKA, P.; KUECHENMEISTER, U.; NUERNBERG, K., LIPTAJ, T.; NUERNBERG, G.;

BAHELKA, I.; DEMO, P.; KUHN, G.; ENDER, K.:

Effect of vitamin $\mathrm{E}$ on changes in phosphorus compounds assessed by 31P NMR spectroscopy and ATPase from post mortem muscle samples and meat quality of pigs. Arch. Tierz., Dummerstorf $\mathbf{4 3}$ (2000), 487-497

LAHUCKY, R.; KRSKA, P.; KUECHENMEISTER, U.; NUERNBERG, K., BAHELKA, I.; DEMO, P.; KUHN, G.; ENDER, K.: Influence of dietary vitamin E supplementation on antioxidative status in muscle and meat quality of pigs. Czech Journal of Animal Science, 46 (2001) 7, 327-332

LAHUCKY, R.; NUERNBERG, K., KUECHENMEISTER, U.; BAHELKA, I.; MOJTO, J.; NUERNBERG, G.; ENDER, K.:

The effect of dietary magnesium oxide supplementation on fatty acid composition, antioxidative capacity and meat quality of heterozygous and normal malignant hyperthermia (MH) pigs. Arch. Tierz., Dummerstorf 47 (2004), 183-191

LEE, B.J.; HENDRICKS, D.G.; CORNFORTH, D.P.:

A comparison of carnosine and ascorbic acid on color and lipid stability in a ground beef pattie model system. Meat Sci. 51 (1999), 245-253 
MANCINI, R.A.; HUNT, M.C.; HACHMEISTER, K.A.; KROPF, D.H.; JOHNSON, D.E.: Ascorbic acid minimizes lumbar vertebrae discoloration. Meat Sci. 68 (2004), 339-345

MARKWELL, M.A.K.; HAAS, S.M.; BIEBER, L.L.; TOLBERT, N.E.:

A modification of the Lowry procedure to simplify protein determination in membrane and lipoprotein samples. Anal. Biochem. 87 (1978), 206-210

MONAHAN, F.J.; ASGHAR, A.; GRAY, J.I.; BACKLEY, D.J.:

Effect of oxidized dietary lipid and vitamin E on the colour stability of pork chops.. Meat Sci. 37 (1994), 205-215

MORRISEY, P.A.; QUINN, P.B.; SHEEHY, P.J.A.:

Newer aspects of micronutrients in chronic disease: vitamin E. Proc. Nutr. Soc. 53 (1994), 571-582

MONTGOMERY, J.L.; PARISH, F.C., Jr.; BEITZ, D.C.; HORST, R.L.; HUFF-LONERGAN, E.J.; TRENKLE, A.H.:

The use of vitamin $\mathrm{D}_{3}$ to improve beef tenderness. J. Anim. Sci., 78 (2000), 2615-2621

NUERNBERG, K.; KUECHENMEISTER, U.; KUHN, G.; NUERNBERG, G.; WINNEFELD K.; ENDER, K.; COGAN, U.; MOKADY, S.:

Influence of dietary vitamin $\mathrm{E}$ and selenium on muscle fatty acid composition in pigs. Food Research International 35 (2002), 505-510

OMAYE, S.T.; TURNBULL, J.D.; SAUBERLICH, H.E.:

Selected methods for the determination of ascorbic acid in animal cells, tissues, and fluids. Methods Enzymol., 62 (1979), 1-7

ROCK. C.L.; FADA, R.D.; JACOB, R.A.; ROWEN P.E.:

Update on the biological characteristics of the antioxidant micronutrients: vitamin $\mathrm{C}$, vitamin $\mathrm{E}$ and the carotenoids. Journal of the American Dietetic Association 96 (1996), 693-702

RUTH, M.S.:

A consumer's dictionary of food additives. (1989). New York: Crown Publishers Inc.

SALIH, A. M.; SMITH, D.M.; PRICE, J.F.; DAWSON, L.E.:

Modified extraction 2-thiobarbituric acid method for measuring lipid oxidation in poultry. Poultry Sci. 66 (1987), 1483-1488

SHEARD, P.R.; TALI, A.:

Injection of salt, tripolyphosphate and bicarbonate marinade solutions to improve the yield and tenderness of cooked pork loin. Meat Sci. 68 (2004) 2, 305-311

SOFOS, J.N.; BUSTA, F.F.:

Alternatives to the use of nitrite as an antibotulinal agent. Food Technology (1980) May, 244-251

WAYLAN, A.T.; O’QUINN, P.R.,; UNRUH, J.A.; NELSSEN, J.L.; GOODBAND, R.D.; WOODWORTH, J.C.; TOKACH, M.D.; KOO, S.I.:

Effects of modified tall oil and vitamin E on growth performance, carcass characteristics, and meat quality of growing-finishing pigs. J. Anim. Sci. 80 (2002), 1575-1585

WONG, P.Y.Y.; WIJEWICKREME, N. A.; KITTS, D.D.:

Fat content and ascorbic acid infusion influence microbial and physicochemical qualities of electron beam irradiated beef patties. Food Chemistry 89 (2005), 93-102

Received: 2005-01-14

Accepted: 2005-09-02

Author's addresses

Dr. RUDOLF LAHUCKY*, IVAN BAHELKA, KATARINA NOVOTNA,

KATARINA VASICKOVA

Research Institute of Animal Production

Hlohovska 2

94991 NITRA

SLOVAK REPUBLIK

*Corresponding Author; E-Mail: lahucky@vuzv.sk

Dr. ULRICH KÜCHENMEISTER, Prof. Dr. Dr. h.c. KLAUS ENDER

Research Institute for Biology of Farm Animals Dummerstorf

Wilhelm-Stahl-Allee 2

18196 DUMMERSTORF

GERMANY 